\title{
CONTROVÉRSIAS SOBRE O CONCEITO DE CONTUMÁCIA NO CRIME DE SONEGAÇÃO FISCAL
}

Resumo: O Supremo Tribunal Federal firmou a tese segundo a qual a conduta de não recolhimento de ICMS, regularmente escriturado e declarado pelo contribuinte, incorre no crime de apropriação indébita tributária, previsto no art. $2^{\circ}$, inciso II, da Lei ${ }^{\circ}$ 8.137/1990. No entanto, a decisão da Suprema Corte introduziu elemento externo novo no referido tipo penal, acerca da necessidade de contumácia no não pagamento do tributo para configuração do crime tributário. O presente trabalho trata da dificuldade quanto à definição deste novel conceito trazido pelo Supremo Tribunal Federal ao crime de sonegação físcal, e, ao fim, apresenta possíveis encaminhamentos da matéria..

Palavras-chaves: Sonegação Fiscal; Criminalização; Supremo Tribunal Federal; Lei $\mathrm{n}^{\circ}$ 8.137/90; Devedor Contumaz

\section{CONTROVERSY OVER CONTUMACY IN TAX EVASION CRIME}

Abstract: The Supreme Court, by majority, upheld the thesis that even though the taxpayer was declared a taxpayer by failing to proceed with due collection, there is no crime of tax misappropriation, establish by article 2 , of the Law $n^{\circ} 8.137 / 1990$. However, the Supreme Court decision introduced a new external element in the referred criminal type, regarding the need for contumacy in the non-payment of the tax for the configuration of the tax crime. The present work deals with this concept brought by the Federal Supreme Court to the crime of tax evasion, at the end, possible referrals of the matter.

Key-Words: Tax evasion; Criminalization; Supreme Court; Law 8.137/90; Persistent Debtor

\section{Introdução.}

O presente artigo tem como escopo analisar os reflexos do julgamento do Recurso Ordinário em Habeas Corpus $n^{\circ}$ 163.334/SC, ocorrido em dezembro de 2019, pelo Supremo Tribunal Federal ("STF”). Antes de adentrar nas nuances do que estabeleceu a Corte Constitucional, importante destacar relevante estudo realizado pela Consultoria Ernest \& Young $E Y^{2}$, o qual demonstrou que os auditores fiscais federais vêm encaminhando mais representação de crimes contra a ordem tributária ao Ministério Público Federal em virtude de a administração tributária entender que os contribuintes não apenas incorrem em erro ao

\footnotetext{
${ }^{1}$ Mestrando em Direito da Regulação pela Escola de Direito do Rio de Janeiro da Fundação Getúlio Vargas FGV Direito Rio. Especializado em Direito Tributário pelo Instituto Brasileiro de Estudos Tributários. Graduado pela Pontifícia Universidade Católica do Rio de Janeiro. Advogado.

${ }^{2}$ https://www.etco.org.br/wp-content/uploads/ETCO-24-WEB.pdf
} 
divergirem do entendimento da Receita Federal do Brasil, como também podem cometer estar cometendo crimes tributários.

Assim, segundo a administração tributária, o simples fato de o contribuinte não proceder ao recolhimento dos seus tributos, já seria suficiente para configurar ilícito tributário, e, possivelmente, à prática de crimes. Nesse cenário, ao lavrar os autos de infração, o fiscal encaminha, concomitantemente, a representação fiscal para fins penais ao Ministério Público para apuração do cometimento de crimes.

No referido estudo elaborado pela Consultoria EY, com base em informações extraídas da Receita Federal do Brasil, constata-se que em 2018, em âmbito federal, esse foi o procedimento adotado em 29,48\% das autuações, contra 25,42\% um ano antes, demonstrando, assim, a correlação entre a cobrança tributária e o direito penal, caracterizando-se como tema de alta relevância. Esses dados, somados à atual posição adotada pelo STF, tornam inegáveis que a política fiscal e a política criminal possuirão cada vez mais pontos de convergência, o que impõe a necessidade de maior rigor na definição de quando começa uma e termina outra.

Dito isto, passa-se ao exame do julgamento do Recurso Ordinário em Habeas Corpus $\mathrm{n}^{\circ}$ 163.334/SC pelo STF, que discutiu o alcance da expressão "descontado ou cobrado, na qualidade de sujeito passivo de obrigação e que deveria recolher aos cofres públicos”, prevista no art. $2^{\circ}$, inciso II, da Lei $n^{\circ} 8.137 / 90^{3}$, para definir se o ato do não recolhimento de ICMSpróprio, devidamente escriturado e declarado ao Fisco, configura crime de sonegação fiscal.

\section{Breves contornos fáticos e jurídicos da decisão da Suprema Corte envolvendo o art. $2^{\circ}$, inciso II, da Lei $\mathbf{n}^{\circ} 8.137 / 1990$.}

Corroborando decisão do Superior Tribunal de Justiça de 2018, entendeu a Suprema Corte, em caso afetado ao plenário ${ }^{4}$, por sete votos a três - frise em decisão não dotada de

\footnotetext{
${ }^{3}$ Art. $1^{\circ}$ Constitui crime contra a ordem tributária suprimir ou reduzir tributo, ou contribuição social e qualquer acessório, mediante as seguintes condutas:

Pena - reclusão de 2 (dois) a 5 (cinco) anos, e multa.(...)

Art. $2^{\circ}$ Constitui crime da mesma natureza: (...)

II - deixar de recolher, no prazo legal, valor de tributo ou de contribuição social, descontado ou cobrado, na qualidade de sujeito passivo de obrigação e que deveria recolher aos cofres públicos;(...)

Pena - detenção, de 6 (seis) meses a 2 (dois) anos, e multa.

4 A sistemática de afetação do julgamento ao plenário de Habeas Corpus que, originalmente, deveriam ser decididos por alguma das Turmas do STF, decorre da atribuição relator ao constar justamente a relevância da discussão jurídica ou ainda para prevenir divergência interpretativa entre Turmas: "quando, em razão da relevância da questão jurídica ou da necessidade de prevenir divergência entre as Turmas, convier pronunciamento do Plenário" (art. 21, XI e Art. 22, RISTF).
} 
efeito erga ommes e ainda não transitada em julgado ${ }^{5}$ - que o contribuinte que, de forma contumaz e com dolo de apropriação, deixa de recolher o ICMS cobrado do adquirente da mercadoria ou serviço, incide no tipo penal do artigo $2^{\circ}$, inciso II, da Lei ${ }^{\circ}$ 8.137/1990, mesmo que o imposto tenha sido declarado pelo contribuinte.

O entendimento majoritário do STF foi, então, no sentido de que o valor do ICMS cobrado do consumidor não integra o patrimônio do comerciante, o qual é mero depositário desse ingresso de caixa que, depois de devidamente compensado, deverá ser recolhido aos cofres públicos. Do contrário, caso não ocorra o devido recolhimento, poderá haver, além do ilícito tributário, o ilícito penal se comprovada, concomitantemente (i) a existência de intenção de praticar o ilícito (dolo); e, ainda, (ii) a contumaz ocorrência do fato ${ }^{6}$.

Não se desconhece que o leading case do STF é um hard case, verdadeira decisão colegiada divisora de águas. Não por outra razão comporta diversas relevantes discussões jurídicas, quais sejam:

(i) a criminalização do mero inadimplemento tributário, já que não se exige a demonstração da ocorrência de animus de fraude, de ardil de omitir e/ou alterar os valores devidos que tenha por objetivo diminuir ou suprimir tributo ou, qualquer outro tipo de artifício para burlar a aplicação do lançamento tributário ${ }^{7}$;

(ii) o fato de que nem sempre o administrador possui o domínio do ato criminoso (sonegação fiscal), já que a mera condição de alguém ocupar cargo de direção dentro de uma estrutura societária complexa, não autoriza a imputação de toda e qualquer responsabilidade por atos ilícitos eventualmente cometidos ${ }^{8}$;

(iii) a (in)constitucionalidade da utilização do direito penal como instrumento de arrecadação tributária (sanção política), em especial diante das Súmulas 70, 323 e 547 do

\footnotetext{
${ }^{5}$ Tratou-se de caso concreto submetido à análise da Suprema Corte (Recurso Ordinário em Habeas Corpus), portanto, não dotado de eficácia geral e efeito vinculante, ainda não transitado em julgado, já que se encontra pendente julgamento de diversos embargos de declaração apresentados. Entretanto, sendo papel da Suprema Corte a derradeira interpretação constitucional da legislação, inegável que a interpretação do STF, em sua composição plenária, tem o condão de pautar a autuação dos Tribunais, Ministérios Públicos, Autoridades Policiais, Procuradorias e Secretarias de Fazenda.

${ }^{6}$ Trecho extraído do voto condutor: "O contribuinte que, de forma contumaz e com dolo de apropriação, deixa de recolher o ICMS cobrado do adquirente da mercadoria ou serviço incide no tipo penal do artigo $2^{\circ}$ (inciso II) da Lei 8.137/1990".

${ }^{7}$ Sobre o tema: BOTTINO, Thiago do Amaral. MACHADO, Gabriel Soares dos Santos; A Criminalização do Inadimplemento do ICMS (Próprio). Revista da Faculdade Mineira de Direito, V. 22, n.44.

${ }^{8}$ SILVA, Paulo Cezar. Crimes contra o Sistema Financeiro Nacional. São Paulo: Quartier Latin, 2006. No mesmo sentido, ALFLEN, Pablo Rodrigo. Teoria do domínio do fato. São Paulo: Saraiva, 2014.
} 
$\mathrm{STF}^{9}$ que rechaçam a utilização de meios oblíquos para forçar o contribuinte ao recolhimento de tributos ${ }^{10}$;

(iv) eventuais efeitos externos que o julgado pode ocasionar ao equiparar quem declara e não paga, aquele que escamoteia a informação ao fisco para não $\operatorname{pagar}^{11}$;

(v) discussão sobre premissas jurídicas e econômicas utilizadas no julgamento como o conceito de "descontado", "cobrado" e repercussão econômica do encargo do tributo ${ }^{12}$;

(vi) se a posição pela criminalização viola o Pacto de San José da Costa Rica, da qual o Brasil é signatário, que não permite prisão por dívida civil ${ }^{13}$;

(vii) se a decisão viola o princípio da razoabilidade e proporcionalidade, já que, para parte significativa da literatura, o Direito Penal é a última ratio e que a intervenção mínima deve ser a tônica de molde a assegurar a sua utilização apenas em face de condutas que se revistam de relevância penal ${ }^{14}$; e,

(viii) inviabilidade da adoção de argumento consequencialista/utilitarista no direito penal, consistente na afirmação de que a criminalização da conduta aumentará a arrecadação com ganhos sociais, notadamente porque não foram sequer apresentados quaisquer dados empíricos ${ }^{15}$.

\footnotetext{
${ }^{9}$ Súmulas 70: É inadmissível a interdição de estabelecimento como meio coercitivo para cobrança de tributo. Súmula 323: É inadmissível a apreensão de mercadorias como meio coercitivo para pagamento de tributos. Súmula 547: Não é lícito à autoridade proibir que o contribuinte em débito adquira estampilhas, despache mercadorias nas alfândegas e exerça suas atividades profissionais.

${ }^{10}$ Notadamente porque no Direito Penal Tributário a punibilidade é excluída nos casos de pagamento do tributo devido, inclusive após o recebimento da denúncia (STF, AP 450, Min. Teori Zavascki, Segunda Turma, j. 18/11/2014) - Lei 9.249/95 - Art. 34. Extingue-se a punibilidade dos crimes definidos na lei $8.137 / 90$, e na lei $4.729 / 65$, quando o agente promover o pagamento do tributo ou contribuição social, inclusive acessórios, antes do recebimento da denúncia.

${ }^{11}$ ANGELO, Tiago. Decisão STF: Equiparar dívida de ICMS declarado a crime é um erro, dizem advogados. Conjur, 2019. Disponível em https://www.conjur.com.br/2019-dez-12/equiparar-divida-icms-declarado-crimeerro (Último acesso: 27.11.2020).

${ }^{12}$ RUIVO, Marcelo Almeida. Os Crimes de Sonegação Fiscal. 2019. (arts. $1^{\circ}$ e $2^{\circ}$, Lei 8.137/90), coletânea Crimes contra Ordem Tributária: do direito tributário ao direito penal. -- São Paulo: Almedina, 2018 p. 443. Também ESTELLITA, Heloisa; JUNIOR, Aldo de Paula. O STF e o RHC 163.334: uma proposta de punição da mera inadimplência tributária? Jota: 2019. Disponível em: https://www.jota.info/opiniao-eanalise/colunas/penal-em-foco/o-stf-e-o-rhc-163-334-uma-proposta-de-punicao-da-mera-inadimplenciatributaria-10122019 (Último acesso: 27.11.2020).

${ }^{13}$ Cf. QUANDT. A apropriação indébita previdenciária e a prisão por dívida. In: LOBATO, José Danilo Tavares; MARTINELLI, João Paulo Orsini; SANTOS, Humberto Souza (Orgs.). Comentários ao Direito Penal Econômico brasileiro. Belo Horizonte: D’Plácido, 2017, p. 467/469.

${ }^{14}$ ANGELO, Tiago. Decisão STF: Equiparar dívida de ICMS declarado a crime é um erro, dizem advogados. Conjur, 2019. Disponível em https://www.conjur.com.br/2019-dez-12/equiparar-divida-icms-declarado-crimeerro (Último acesso: 27.11.2020).

${ }^{15}$ SOARES, Hugo. Podem ser legítimos crimes sem referência a bens jurídicos-penais? Elementos para uma teoria sentimentalista do valor jurídico-penal. Revista Brasileira de Ciências Criminais, n. 147, 2018.
} 
É inegável a importância das relevantes questões jurídicas acima citadas, que, por certo, demandam ainda novas reflexões, contudo, o que se pretende neste trabalho é tratar de outra relevante questão: o novo conceito jurídico de devedor contumaz, verdadeiro 'elemento externo’ trazido pela Suprema, condição necessária para que seja então aplicado o direito penal à inadimplência tributária.

Afinal o que é esse 'devedor contumaz'? Sabendo que tal conceito é uma das peças importantes nesse relevantíssimo tema jurídico, questão acentuada que, contudo, não se presta a esgotar as diversas facetas da matéria.

\subsection{A posição firmada pelo Supremo Tribunal Federal.}

Através de extenso acórdão, que consta com 210 laudas, por maioria de votos, prevaleceu a corrente capitaneada pelo voto do ministro Relator Roberto Barroso, que estabeleceu as como premissas no equacionamento da matéria, dentre outras questões, que: o mero inadimplemento tributário não deve ser tido como fato típico criminal; para que seja reconhecida a tipicidade de determinada conduta, impende haver um nível de reprovabilidade especial que justifique o tratamento mais gravoso.

Explicitou, ainda, que o sujeito ativo do crime é o passivo da obrigação que, na hipótese do ICMS próprio, é o comerciante, sendo o objeto do delito o valor do tributo, no caso, a quantia transferida pelo consumidor ao comerciante.

A utilização dos termos "descontado" e "cobrado" é o ponto central do dispositivo legal em análise, posto que tributo descontado se refere aos tributos diretos, já a expressão do texto legal "cobrado" abarca o contribuinte nos tributos indiretos. Portanto, "cobrado" significa o tributo que é acrescido ao preço da mercadoria, pago pelo consumidor contribuinte de fato - ao comerciante, que deve recolhê-lo ao Fisco. Ao assim consignar, o voto vencedor abriu verdadeira possibilidade da aplicação do referido tipo penal a todo e qualquer tributo, seja ele tributo direto ou indireto.

Salientou, ainda, o Ministro relator, que o valor do ICMS cobrado em cada operação não integra o patrimônio do comerciante, que é depositário desse ingresso de caixa. Dessa maneira, a conduta não equivale a mero inadimplemento tributário, e sim à apropriação indébita tributária. A reprovabilidade está em tomar para si o valor que não lhe pertence. Para caracterizar o tipo penal, a conduta é composta da cobrança do consumidor e do não recolhimento ao Fisco. 
Segundo o relator, a interpretação histórica também conduz à tipicidade da conduta. $\mathrm{Na}$ redação apresentada em substitutivo ao projeto de lei original, tratava-se, em incisos separados, a hipótese de retenção e não recolhimento e a hipótese de cobrança no preço e não recolhimento. No texto final aprovado, o dispositivo foi compactado sem a modificação do sentido da norma, fundiu os dois incisos em um só e dispôs os termos "descontado", para o tributo retido na fonte, e "cobrado", para o tributo incluído no preço.

$\mathrm{O}$ voto do Ministro relator discorre ainda que a livre iniciativa resta afetada pela conduta, na qual empresas que sistematicamente deixam de recolher o imposto colocam-se em situação de vantagem competitiva em relação as que se comportam corretamente, podendo, por exemplo, serem capazes de alijar os concorrentes que cumprem suas obrigações.

Assentada a possibilidade do delito em tese, o voto condutor assinalou que o crime de apropriação indébita tributária não comporta a modalidade culposa. É imprescindível a demonstração do dolo ${ }^{16}$ e não será todo devedor de ICMS que cometerá o delito. O inadimplente eventual distingue-se do devedor contumaz. O devedor contumaz faz da inadimplência tributária seu modus operandi.

Acompanhado pela maioria dos Ministros, houve destaque no voto da Ministra Rosa Weber ao consignar que a conduta eleita pelo legislador penal não exige, para sua perfectibilização, o emprego de fraude ou simulação pelo contribuinte, nem qualquer omissão.

Restaram vencidos no julgamento não unânime os Ministros Gilmar Mendes, Ricardo Lewandowski e Marco Aurélio, que deram provimento ao recurso por considerarem a conduta atípica.

\section{A inovação no tipo penal do art. $2^{\circ}$, inciso II, da Lei $n^{0} 8.137 / 1990$ trazida pelo Supremo Tribunal Federal: Contumácia no inadimplemento.}

Conforme já adiantado alhures, não se adentrará na discussão acerca das diversas teorias sobre a presença do dolo neste crime e ainda de eventuais dificuldades da configuração do dolo no crime de sonegação fiscal ${ }^{17}$, mas, sim, sobre o conceito de devedor contumaz, que,

\footnotetext{
${ }^{16}$ Consignou que o dolo da apropriação deve ser apurado na instrução criminal, pelo juiz natural da causa, a partir de circunstâncias objetivas e factuais, tais como a inadimplência reiterada, a venda de produtos abaixo do preço de custo, a criação de obstáculos à fiscalização, a utilização de "laranjas", a falta de tentativa de regularização de situação fiscal, o encerramento irregular de atividades com aberturas de outras empresas.

${ }^{17}$ Pontua-se sobre a questão do solo que parte significativa da doutrina entende que há dono genérico apenas pelo fato de se constatar o não recolhimento do tributo, não havendo necessidade de mais elementos.

Ressalto que não há necessidade de comprovação do dolo de se apropriar dos valores destinados à previdência social. O dolo do crime de apropriação indébita previdenciária é a vontade de não repassar à previdência as contribuições recolhidas, dentro do prazo e das formas legais, não se exigindo o animus rem sibi havendi, sendo,
} 
ao que tudo indica, será o principal critério distintivo para evitar que (perigosamente) nos aproximemos do emprego da sanção penal contra toda e qualquer inadimplência tributária.

Importante destacar que, em que pese o caso concreto tratado no mencionado leading case versar sobre o tributo estadual indireto (ICMS), não se trata de tipo penal exclusivo do referido tributo $^{18}$, sendo certo que as balizas definidas pela Suprema Corte serão utilizadas para criminalização pelo inadimplemento de outros tributos que não somente o tributo estadual indireto $^{19}$, nesse sentido, destaca-se o seguinte trecho do voto do Ministro Alexandre de Moraes, que acompanhou o voto condutor, no referido julgado ${ }^{20}$ :

De início, depreende-se que a necessidade da configuração da contumácia conflita com a hermenêutica tradicional que rege o direito penal, na qual se aplica a tipicidade penal cerrada para reger os tipos penais, isto porque, através de uma interpretação gramatical é inegável que tal elemento não faz parte do texto legal.

Seja como for, diante da recente posição da Suprema Corte, se torna condição necessária de investigação para configuração do referido crime de sonegação fiscal a contumácia, afinal, nas palavras do voto condutor: "Não se trata de criminalização da inadimplência, mas da apropriação indébita. Estamos enfrentando um comportamento empresarial ilegítimo".

portanto, descabida a exigência de se demonstrar o especial fim de agir ou dolo específico de fraudar a Previdência Social, como elemento essencial do tipo penal. Aliás, o próprio STF já decidiu, conduzido pelo Ministro Ayres Britto, que, "quanto ao delito de apropriação indébita previdenciária, o elemento subjetivo animador da conduta típica do crime de sonegação de contribuição previdenciária é o dolo genérico, consistente na intenção de concretizar a evasão tributária". (PAULSEN, Leonardo. Curso de Direito Tributário Completo. Saraiva, São Paulo, 8 ed. 2017). No mesmo sentido, posição do STJ no EREsp 1.296.631-RN, Rel. Min. Laurita Vaz, julgado em 11/9/2013.

${ }^{18}$ O STF ao não diferenciar o conceito de tributo cobrado do conceito de tributo descontado, abriu a possibilidade de aplicação do referido tipo penal a todo e qualquer tributo não pago, caso presente o dolo e a contumácia.

${ }^{19}$ Sobre a questão - Cezar Roberto Bitencourt em seu Tratado de Direito Penal Econômico. O sujeito ativo do crime pode ser tanto a pessoa física responsável pelo pagamento do tributo como o próprio contribuinte. Com efeito, aquele que deixa de recolher o tributo descontado de outrem corresponde a figura do responsável tributário em sentido estrito, sujeito que, sem revestir a condição de contribuinte, é obrigado em face de expressa disposição de lei. (...) o responsável também pode ser sujeito ativo do crime quando deixa de recolher o valor do tributo cobrado de terceiros. Nesse caso, a cobrança normalmente incide sobre tributos indiretos (como o IOF). O contribuinte, igualmente, pode figurar como sujeito ativo. Imagine se, por exemplo, a hipótese do autônomo prestador de serviço, que por meio de convenção particular passa para o seu cliente (tomador do serviço), de forma específica, os gastos com o pagamento do ISS e do IRPF, e deixa de recolher em favor do estado o valor dos impostos devidos. (C BITENCOURT, Cezar Roberto. Tratado de Direito Penal Econômico, volume 1, são Paulo, ed. Saraiva, 2016, p. 757)

${ }^{20}$ A própria tese defensiva que tem por objetivo restringir o tipo penal à hipótese da substituição tributária (excluindo, pois, o famigerado "Icms próprio"), não leva em consideração a terminologia adotada pelo legislador para a identificação do sujeito ativo do crime: o sujeito ativo do crime é o sujeito passivo da obrigação tributária. E como o legislador não fez qualquer distinção no tipo penal (justamente por querer se referir a ambas as espécies de sujeição passiva), não cabe ao intérprete e ao julgador fazê-lo. (grifo do original) 
É realidade do sistema capitalista, em especial na situação de estagnação econômica no Brasil, agravada pela Pandemia do Covid-19, que diversos empresários, não conseguem quitar todos os tributos e os salários dos empregados.

Em regra, agindo dentro do balizamento legal, o empresário declara o que de fato deve, mas não efetua o pagamento, esperando que a situação futura melhore para que possa então, quitar os tributos atrasados, ou aguarda, por exemplo, que seja editada alguma norma superveniente de parcelamento/desconto mais vantajoso, ou, ainda, simplesmente ao longo do tempo reconheça que não é mais possível soerguer a sociedade encerrando a atividade de insucesso empresarial.

O insucesso empresarial, notadamente o malogro momentâneo, deve ser reconhecido como situação jurídica e econômica corriqueira, inclusive as diversas possibilidades legais de soerguimento devem ser protegidas pelo Estado. Não por outra razão, o Brasil possui uma moderna lei de recuperação judicial em franca utilização (Lei no 11.101/05).

Nesta toada, em regra, a atitude de declarar o que deve ao fisco teria o condão de isentar o dolo da apropriação, já que evidencia que de fato, o empresário não quer lesar o Fisco, se apropriando do valor do imposto, ao contrário, reconhece que tem uma dívida tributária e que não consegue/pode pagá-la no momento. Em outras palavras, não há fraude, omissão ou falsidade nas informações/escriturações prestadas ao fisco. Da mesma forma que se insere dentro das decisões empresariais quando e como pagar seus tributos que não devem sofrer intervenção estatal.

Por outro lado, não se nega que os contribuintes possuem um dever fundamental de pagar seus tributos, afinal, em especial com os recursos advindos dos impostos, o Estado faz frente às suas obrigações, atendendo as demandas sociais, já que, a rigor, o Estado não é gerador de riqueza.

Não há, como é de conhecimento geral, direitos ou garantias absolutas ${ }^{21}$. Não se pode, então, diante disso, emprestar uma exegese absoluta e despregada da realidade maior do sistema. Tem-se, portanto, em um lado do espectro constitucional, o direito à livre atividade

\footnotetext{
${ }^{21}$ Até porque não se interpreta a Constituição por tiras, ou aos pedaços, nem ao modo do "tudo ou nada", orientado por uma lógica formal subjuntiva, e cada vez mais desacreditada, que se expressa, em sua simplicidade, na seguinte equação: verificado o fato A, então aplica-se a regra B.
} 
econômica lícita e, do outro lado, o dever fundamental de pagar tributos. Não se pode, aqui, enfim, olhar a árvore sem ver a floresta ${ }^{22}$.

Feitas essas considerações, diante do decidido pela Suprema Corte, evitando que o mero inadimplemento tributário possa ser considerado crime em qualquer hipótese, e obstando que o direito penal seja aplicado indevidamente para tema eminentemente tributário, resta necessário compreender o conceito de devedor contumaz.

O trabalho do intérprete sobre o conceito de devedor contumaz possui uma primeira dificuldade decorrente do fato de que não há no referido tipo penal (art. $2^{\circ}$, inciso II, da Lei no 8.137/1990) qualquer alusão ou definição do conceito de devedor contumaz. Ato contínuo, qualquer análise se torna ainda mais tormentosa pelo fato de que não há outra norma federal, seja de matiz penal, seja de matiz tributária ou concorrencial, que traga definição sobre o conceito de contumácia.

Nesse cenário nebuloso, não há legislação federal integrativa que possa socorrer, para fins de integração do tipo penal, a exemplo do que deveria ser esperado em uma tradicional norma penal em branco ${ }^{23}$.

\section{Projetos de lei sobre devedor contumaz.}

A Constituição Federal, em seu artigo $146-\mathrm{A}^{24}$, prevê o advento de lei complementar que poderá estabelecer critérios especiais de tributação com o objetivo de prevenir desequilíbrios da concorrência. No entanto, mesmo depois de dezessete anos da emenda constitucional $n^{\circ} 42$ que introduziu o referido artigo na Carta Maior, ainda não há legislação específica sobre a matéria.

\footnotetext{
22 "Não há, no sistema constitucional brasileiro, direitos ou garantias que se revistam de caráter absoluto, mesmo porque razões de relevante interesse público ou exigências derivadas do princípio da convivência das liberdades legitimam, ainda que excepcionalmente, a adoção, por parte dos órgãos estatais, de medidas restritivas das prerrogativas individuais ou coletivas, desde que respeitados os termos estabelecidos pela própria Constituição. O estatuto constitucional das liberdades públicas, ao delinear o regime jurídico a que estas estão sujeitas - e considerando o substrato ético que as informa - permite que sobre elas incidam limitações de ordem jurídica, destinadas, de um lado, a proteger a integridade do interesse social e, de outro, a assegurar a coexistência harmoniosa das liberdades". (STF, RE n 491.336, Min. Celso de Mello, j. 15.9.2006, DJ 2.10.2006)

${ }^{23}$ Modalidade em que o preceito é incompleto, devendo ser integrado por outra norma. HORCAIO, Ivan. Dicionário Jurídico. São Paulo: Primeira Impressão, 2008. p. 1258.

${ }^{24}$ Art. 146-A. Lei complementar poderá estabelecer critérios especiais de tributação, com o objetivo de prevenir desequilíbrios da concorrência, sem prejuízo da competência de a União, por lei, estabelecer normas de igual objetivo.
} 
Há, todavia, dois projetos de lei em tramitação perante o Congresso Nacional que visam justamente normatizar a definição da figura do devedor contumaz, o Projeto de Lei do Senado $n^{\mathrm{o}} 284 / 2017^{25}$ e o Projeto de Lei n $\mathrm{n}^{\mathrm{o}} 1.646 / 2019^{26}$.

O propósito do PLS n ${ }^{\circ}$ 284/2017, já aprovado nas Comissões de Assuntos Econômicos e de Transparência, Governança, Fiscalização e Controle e Defesa do Consumidor do Senado, é justamente distinguir objetivamente os tipos de devedores: (a) o devedor eventual, para o qual nada muda; (b) o devedor reiterado, que também continuará contando com as atuais proteções legais, desde que não utilize a vantagem tributária para praticar concorrência desleal; e, (c) o devedor contumaz, alvo da lei.

Trata-se de norma que visa assegurar minimante alguns procedimentos para que o devedor seja considerado contumaz, não prevendo valores ou periodicidade, mas deixando a fixação de tais questões à outras normas a serem editadas, assegurando o direito de defesa prévio para que seja reconhecido um devedor contumaz, inclusive com a necessidade de duplo grau de julgamento ${ }^{27}$.

Já o Projeto de Lei no 1.646/19 prevê que, para se considerar um devedor contumaz, é imprescindível haver inadimplência substancial, isto é, a ocorrência de débitos em aberto em montante superior a 15 milhões de reais e em período superior a um ano ${ }^{28}$, podendo referido valor ser alterado pelo Ministro da Econômica ${ }^{29}$.

Por esse projeto de lei, também só se considerará, para tal montante, valores que não estejam garantidos ou com a exigibilidade suspensa (art. 151, Código Tributário Nacional ${ }^{30}$ ). Por fim, também há necessidade de procedimento administrativo prévio ${ }^{31}$ que assegure a ampla defesa para configuração do devedor contumaz.

\footnotetext{
${ }^{25}$ Projeto de Lei do Senado n ${ }^{\mathrm{o}} 284$, de 2017.

${ }^{26}$ Projeto de Lei $n^{\circ} 1.644$, de 2019.

27 a) intimação prévia do sujeito passivo para exercício do direito de defesa, em prazo não inferior a quinze dias, e assegurada a interposição de recurso, sem efeito suspensivo, que deverá ser apreciado em até noventa dias, sob pena de imediato cancelamento do regime diferenciado;

${ }^{28}$ Art. $2^{\circ}$ (...) "Para fins do procedimento de que trata o caput, considera-se inadimplência substancial e reiterada de tributos a existência de débitos, em nome do devedor ou das pessoas físicas ou jurídicas a ele relacionadas, inscritos ou não em dívida ativa da União, de valor igualou superior a R\$ 15.000.000,00 (quinze milhões de reais\}, em situação irregular por período igualou superior a um ano.

${ }^{29}$ Art. $2^{\circ}(\ldots) 3^{\circ} \mathrm{O}$ valor estabelecido no $\S 1^{\circ}$ poderá ser atualizado em ato do Ministro de Estado da Economia.

${ }^{30}$ Art. $2^{\circ}(\ldots) \S 2^{\circ}$ Considera-se em situação irregular o crédito tributário que não esteja garantido ou com exigibilidade suspensa, observado o disposto no art. 206 da Lei no 5.172, de 25 de outubro de 1966 Código Tributário Nacional.

${ }^{31}$ Art. $2^{\circ}$ Os órgãos da administração tributária da União poderão instaurar procedimento administrativo para caracterização e aplicação de restrições administrativas ao devedor contumaz, quando houver:
} 
Os referidos projetos de leis não fazem qualquer referência aos crimes tratados na Lei $\mathrm{n}^{\circ} 8.137 / 1990$ ou, sequer sobre algum aspecto criminal. Seja como for, considerando a recente decisão da Suprema Corte, salutar caminho possível é que o debate possa retornar ao Congresso Nacional para, aperfeiçoando o texto legislativo, trazer uma maior segurança jurídica sobre a diferenciação de devedor contumaz e devedor eventual, inclusive para fins de aplicação na seara criminal especificamente para o tipo penal em análise, mesmo que não seja esse o foco original dos referidos projetos de lei.

Nessa toada, uma das considerações que já se pode inferir é no sentido de que, diante da ausência de normas específicas, há manifesto risco de divergência interpretativa, o que, em última análise, terá o condão de, em situações fáticas análogas, existirem casos em que ocorrerá a criminalização/denúncia de empresários e outros que não, conforme a interpretação pessoal de cada órgão envolvido ao constatar se tal situação configurou ou não contumácia, ocasionando indesejada insegurança jurídica.

\section{Conceito de contumácia em normas estaduais.}

A publicação pelos Estados de legislações específicas sobre devedores contumazes visa regular a criação de regimes especiais de acompanhamento de fiscalização para devedores do fisco ${ }^{32}$ sem embasar processo criminal, no entanto, inegável que agora poderão representar importante base normativa para acepção de devedor contumaz para definição do crime de que trata o art. $2^{\circ}$, inciso II, da Lei $n^{\circ} 8.137 / 90$, notadamente diante da ausência de legislação federal sobre a matéria, conforme já tratado acima.

Antes da decisão do Superior Tribunal de Justiça sobre a criminalização do não recolhimento do ICMS, em agosto de 2018, que restou confirmada pelo STF em 2019, seis Estados já tinham leis sobre esse tema: Rio Grande do $\mathrm{Sul}^{33}$, São Paulo ${ }^{34}$, Santa Catarina ${ }^{35}$, Espírito Santo ${ }^{36}$, Paraná $^{37}$, Bahia ${ }^{38}$. Posteriormente, mais quatro Estados publicaram normas no período, Mato Grosso ${ }^{39}$, Paraíba $^{40}$, Maranhão ${ }^{41}$ e Rio Grande do Norte ${ }^{42}$. Há ainda Estados

\footnotetext{
${ }^{32}$ Regimes especiais de fiscalização podem ser definidos como situações em que verificada situação de maior risco de sonegação de tributos, há o aproveitamento de técnicas capazes de facilitar a fiscalização e a arrecadação, sendo exigência crescente utilizadas pelos fiscos, mormente quando se comprova que os meios usuais não conseguem sustar a evasão, dando azo a distorções no mercado concorrencial.

${ }^{33}$ Decreto Estadual $\mathrm{n}^{\circ} 48.494$, de 31 de outubro de 2011.

${ }^{34}$ Lei Complementar Estadual no ${ }^{\circ} 1.320$, de 06 de abril de 2018.

${ }^{35}$ Lei Estadual ${ }^{\circ} 3.938$, de 22 de dezembro de 1966.

${ }^{36}$ Decreto Estadual n. ${ }^{\circ} 3.200$-R, de 10 de janeiro de 2013.

${ }^{37}$ Lei Estadual $n^{\circ} 11.580$, de 14 de novembro de 1996.

${ }^{38}$ Lei Estadual n ${ }^{\circ} 7.014$, de 04 de dezembro de 1996.

${ }^{39}$ Lei Estadual n ${ }^{\circ} 7.098$, de 30 de dezembro de 1998.
} 
que até o momento não possuem legislação específica sobre a matéria, como é o caso do Rio de Janeiro.

Ponto inicial de reflexão sobre as legislações estaduais se deve ao fato de que os critérios para ser considerado um devedor reiterado variam de Estado para Estado, por exemplo, deixar de pagar o ICMS por três meses consecutivos.

Este parâmetro, definido no Rio Grande do Norte, é suficiente para que um contribuinte seja considerado um devedor contumaz ${ }^{43}$, no entanto, tal circunstância não configuraria contumácia no Rio Grande do $\mathrm{Sul}^{44}$ e no Paraná ${ }^{45}$, já que nestes Estados basta que o contribuinte deixe de recolher os impostos declarados pelo período de oito meses dos últimos doze (não necessariamente seguidos), para incorrer na definição local de devedor contumaz.

Além da ausência de uniformização do critério temporal sobre a ausência de recolhimento pelas legislações estaduais, há também enorme discrepância de critérios de ordem quantitativa.

Dívidas de R\$250 mil e R $\$ 500$ mil, para alguns Estados, já podem configurar a situação de devedor contumaz, como é o caso de Pernambuco ${ }^{46}$ e de Alagoas ${ }^{47}$,

\footnotetext{
${ }^{40}$ Lei Estadual $\mathrm{n}^{\circ} 11.247$, de 13 de dezembro de 2018.

${ }^{41}$ Lei Estadual n ${ }^{\circ} 5,826$ de 20 de dezembro de 2013.

${ }^{42}$ Lei Estadual no 10.497 de 15 de março de 2019.

${ }^{43}$ Lei Estadual n ${ }^{\circ} 10.497$ de 15 de março de 2019.
}

Art. 10. Será considerado devedor contumaz, para efeito desta Lei, o contribuinte que:

I - deixar de recolher o imposto devido por 3 (três) meses consecutivos ou 6 (seis) meses alternados; ou

${ }^{44}$ Decreto Estadual $\mathrm{n}^{\circ} 48.494$, de 31 de outubro de 2011.

Art. $1^{\circ}$ - Com fundamento no art. $2^{\circ}$ da Lei $n^{\circ} 13.711$, de 6 de abril de 2011, considera-se devedor contumaz o contribuinte que: I - deixar de recolher débitos declarados em Guia de Informação e Apuração do ICMS - GIA, em 8 (oito) meses de apuração do imposto nos últimos 12 (doze) meses anteriores ao corrente, considerados todos os estabelecimentos da empresa; ou (...)

${ }^{45}$ Lei Estadual ${ }^{\circ} 11.580$, de 14 de novembro de 1996.

Art. 52. A fim de resguardar a correta execução desta Lei, a Coordenação da Receita do Estado da Secretaria de Estado da Fazenda poderá determinar regime especial de controle, de fiscalização e de pagamento aos contribuintes considerados devedores contumazes, visando ao cumprimento de obrigações, conforme definido pelo Poder Executivo.

$\S 1^{\circ}$ Considera-se devedor contumaz o contribuinte que: I - considerando cada estabelecimento, deixar de recolher o ICMS declarado em Guia de Informação e Apuração do ICMS - GIA/ICMS, Guia Nacional de Informação e Apuração do ICMS Substituição Tributária - GIA-ST ou apurado por meio da Escrituração Fiscal Digital - EFD, no todo ou em parte, relativo a oito períodos de apuração do imposto, consecutivos ou não, nos doze meses anteriores, podendo a quantidade de períodos ser alterada a critério do Poder Executivo; ou (...)

${ }^{46}$ Lei Estadual no 11.514 de 29 de dezembro de 1997

Art. 18-A. A partir de $1^{\circ}$ de setembro de 2013 , será considerado devedor contumaz o contribuinte que: (...)

III - tiver créditos tributários inscritos em Dívida Ativa, em valor que ultrapasse:

a) $\mathrm{R} \$ 500.000,00$ (quinhentos mil reais), considerados todos os estabelecimentos da empresa; ou

${ }^{47}$ Lei Estadual n ${ }^{\circ} 7.747$ de 9 de outubro de 2015

Art. 60-A. Poderá ser submetido a Regime Especial de Controle de Fiscalização o sujeito passivo que: 
respectivamente. Trata-se de valores relativamente baixos, de forma que todo grande contribuinte possuiria risco potencial em figurar como devedor contumaz. Por outro lado, outros Estados utilizam diferentes critérios, baseados em percentual do patrimônio líquido ou faturamento anual inscrito em dívida ativa, vide o caso do Paraná. ${ }^{48}$

A vastidão de critérios distintos demonstra que, diante da autonomia legislativa em matéria tributária estadual, não há parâmetros minimamente uniformes. No âmbito tributário, mesmo não sendo o cenário ideal que cada Estado possua uma legislação tributária completamente diferente entre si - já que ocasiona aumento do custo do País, dado o elevado ônus de conhecer e cumprir legislações diversas -, não se vislumbra qualquer discussão sobre a ilegalidade ou inconstitucionalidade dos Estados legislarem sobre a definição de devedor contumaz, considerando a autonomia da esfera de competência definida pela Constituição Federal (art. 155 da CF).

Porém, a situação se altera ao utilizar parâmetros exclusivamente estaduais para implicações na esfera penal, isso porque há filtro de constitucionalidade de difícil superação, já que está previsto no art. 22, I da Constituição Federal ${ }^{49}$, que a matéria penal é de competência legislativa privativa da União e indelegável ${ }^{50}$.

Ademais, sem necessidade de maior esforço exegético, não se revela minimamente razoável que condutas idênticas tenham tratamento penal diverso apenas diante do fato de terem ocorrido em uma ou outra unidade da federação. A ruptura com a isonomia, no caso, seria assaz evidente.

Por outro lado, sem necessidade de aprofundar o estudo sobre a roupagem normativa, mesmo caso fosse possível conceber algum critério jurídico-valorativo para fins de aplicação

I - for considerado devedor contumaz, assim entendido aquele que: (...) c) tiver créditos tributários inscritos em Dívida Ativa, em valor que ultrapasse: 1 . $\mathrm{R} \$ 250.000,00$ (duzentos e cinquenta mil reais), considerados todos os estabelecimentos da empresa; (...).

${ }^{48}$ Lei no 11.580 , de 14 de novembro de 1996

Art. 52. A fim de resguardar a correta execução desta Lei, a Coordenação da Receita do Estado da Secretaria de Estado da Fazenda poderá determinar regime especial de controle, de fiscalização e de pagamento aos contribuintes considerados devedores contumazes, visando ao cumprimento de obrigações, conforme definido pelo Poder Executivo.

$\S 1^{\circ}$ Considera-se devedor contumaz o contribuinte que: (...) II - considerando todos os estabelecimentos da empresa, tiver créditos tributários inscritos em dívida ativa em valor superior a: a) 30\% (trinta por cento) do patrimônio da empresa; ou b) 30\% (trinta por cento) do faturamento anual declarado em GIA/ICMS, em GIA-ST ou em EFD.

${ }^{49}$ Art. 22. Compete privativamente à União legislar sobre: I - direito civil, comercial, penal, processual, eleitoral, agrário, marítimo, aeronáutico, espacial e do trabalho;

${ }^{50}$ É inconstitucional a lei distrital ou estadual que comine penalidades a quem seja flagrado em estado de embriaguez na condução de veículo automotor. (ADI 3.269, rel. min. Cezar Peluso, j. 1ํ-8-2011, P, DJE de 22-92011). 
de matéria penal advindo dos normativos estatais sobre devedor contumaz, há ainda outra problemática decorrente do fato de que diversas legislações estaduais que regulam a matéria sequer se encontram previstas em lei, mas, sim, apenas em atos infralegais (decretos), o que também transborda de patente inconstitucionalidade no âmbito penal diante da tipicidade cerrada.

Assim, entende-se que a adoção de critérios de devedor contumaz previstos em legislações estaduais não devem se prestar a conduzir consequências penais, em especial para fins de definição do crime previsto no art. $2^{\circ}$, inciso II, da Lei ${ }^{\circ}$ 8.137/90, no limite, podem ser ponto de partida interpretativo diante da total ausência de norma federal.

\section{A literatura sobre devedor contumaz.}

Diante do contexto exposto até aqui, compreende-se que o novo conceito de devedor contumaz trazido pela Suprema Corte não possui normatização no âmbito federal, não podendo ser extraído a fórceps das legislações estaduais.

A garantia ao livre exercício de atividade econômica, assim como o dever fundamental de pagar tributos, não são absolutos, mas passíveis de serem condicionadas pela ordem jurídica. Cabe, então, ao Estado regular e estabelecer as normas que lastrearão o exercício da atividade de persecução criminal, sempre tendo em vista o bem-estar social, isto é, o princípio do livre exercício da atividade econômica encontra limites em situações especiais.

Está-se diante, pois, de genuíno hard case, isto é, de caso que não admite, para sua solução, uma mera e simplista aplicação subjuntiva da norma, mas, antes, deve ser resolvido à luz da pluralidade normativa de dado sistema jurídico, sob a regência decisiva das normas de princípio.

Como se vê, valores constitucionais plúrimos (liberdade de exercer atividade econômica, e os limites que, para tanto, devem ser observados, em prol da própria coletividade, em sentido amplo), de igual dignidade e hierarquia, e que encerram interesses difusos, estão, aqui, lado a lado, em aparente, e só aparente sublinhe-se, contradição, devendo, 
pois, ser harmonizados, mediante labor interpretativo de concretização ${ }^{51}$ e concordância prática. $^{52}$

Para tanto, e como se dá em toda e qualquer questão genuinamente constitucional, há que se ampliar o horizonte cognitivo fático e jurídico da matéria, à luz da abertura do sistema e da pluralidade normativa que o notabiliza, e, sobretudo, à luz da realidade social, em função da qual a Constituição deve ser concretizada. A esse respeito, cite-se a lição de Konrad Hesse $^{53}$.

Nesse contexto, e considerando, como assinala Paulo Bonavides, ${ }^{54}$ que "direito e realidade não são esferas incomunicáveis nem categorias autônomas subsistentes por si mesmas", e que "o âmbito da norma é fator que fundamenta a normatividade", há que considerar que apenas em situações excepcionalíssimas o direito penal deve tutelar o não pagamento de tributo.

Isto é, no caso de evidente e manifesto abuso de direito, aí sim se faz presente a figura de sonegação fiscal, de forma que permita, aos que dela se valem, ou mesmo, o que é pior, aos que fazem dela uma estratégia empresarial para amealhar ganhos ilícitos e prática de preços predatórios, desleais e parasitários (para não falar em dumping), muito abaixo dos custos de produção, criando, com isso, condições artificiais de iníqua desigualdade entre os agentes econômicos. Mais além: retira o lugar ao sol dos players que cumprem a lei e exercem

\footnotetext{
${ }^{51}$ Segundo Friedrich Müller, a experiência jurídica se apresenta sob a forma de uma concretização (= obtenção, construção) de normas jurídicas (MULLER, Friedrich Discours de la Méthode Juridique, Paris, PUF, 1996, p. $135)$.

${ }^{52}$ Nesse sentido, assinala Alexandre de Moraes, citando Gomes Canotilho, que "a interpretação constitucional deve ser realizada de maneira a evitar contradições entre suas normas. Assim, a análise sistêmica do texto magno é impositiva e primordial, pois, como salienta Canotilho, o intérprete deve 'considerar a constituição na sua globalidade e procurar harmonizar os espaços de tensão existentes entre as normas constitucionais a concretizar. A necessidade de interpretar-se a Constituição de forma una demonstra a interdependência e complementaridade das normas constitucionais, que não poderão, sob pena de desrespeito à vontade do legislador constituinte, ser interpretadas isoladamente" MORAES, Alexandre. Constituição do Brasil Interpretada. São Paulo, Atlas, 2005. p.109).

53 A norma constitucional não tem existência autônoma em face da realidade. A sua essência reside na sua vigência, ou seja, a situação por ela regulada pretende ser concretizada na realidade. Essa pretensão de eficácia não pode ser separada das condições históricas de sua realização (...) devem ser contempladas aqui as condições naturais, técnicas, econômicas e sociais. A pretensão de eficácia da norma jurídica somente será realizada se levar em conta essas condições (...). A interpretação constitucional está submetida ao princípio da ótima concretização da norma. Evidentemente, esse princípio não pode ser aplicado com base nos meios fornecidos pela subsunção lógica e pela construção conceitual. Se o direito e, sobretudo, a Constituição, têm a sua eficácia condicionada pelos fatos concretos da vida, não se afigura possível que a interpretação faça deles tabula rasa. Ela há de contemplar essas condicionantes, correlacionando-as com as proposições normativas da Constituição. A interpretação adequada é aquela que consegue concretizar, de forma excelente, o sentido ( $\operatorname{sinn}$ ) da proposição normativa dentro das condições reais dominantes numa determinada situação. (HESSE, Konrad, A Força Normativa da Constituição, PA, Sergio Antonio Fabris, 1991, pp. 14, 22/24).

${ }^{54}$ BONAVIDES, Paulo, Curso de Direito Constitucional, São Paulo: Malheiros, 1998, p. 463.
} 
atividade lícita, à luz dos princípios, fins e valores da ordem econômica, além, é claro, de extrair o custeio do Estado.

Apenas nessas situações peculiares entende-se que a inadimplência sistemática pode se transmutar em sonegação fiscal, já que cria, enfim, uma realidade tão anti-isonômica, quanto cruel: fulmina e condena ao alijamento do mercado aqueles que nele regularmente ingressaram e que cumprem com as normas legais, e favorece e alavanca aqueles que ali se instalam à sorrelfa da legalidade, implicando em lucros excessivos ao empresário, e, por fim, deixa o Estado à mingua de recursos.

Essas condutas, apenas quando completamente destoantes dos fins e valores constitucionais, que quando provado que se trata de uma política empresarial estratégica, decidem deliberadamente não recolherem seus tributos, devem ser repelidas com o direito penal. Afinal, na clássica lição de Fábio Konder Comparato, "o poder econômico é uma função social, de serviço à coletividade" ${ }^{\natural 5}$, logo possível arrematar que a liberdade de iniciativa se legitima quanto voltada à efetiva consecução desses fundamentos, fins e valores da ordem econômica.

De fato, a empresa que sistematicamente sonega tributos descumpre sua função social e esse descumprimento demonstra que tal empresa não se acomoda aos valores sociais da livre iniciativa (Constituição Federal, arts. $1^{\circ}$, IV, e 170), que são, de um lado, a possibilidade de os sujeitos econômicos regularem suas relações do modo que lhes seja mais conveniente, garantia a cada um para desenvolver livremente a atividade escolhida, e, de outro, submissão à função social da empresa, ao dever do empresário de propiciar melhores condições de vida aos trabalhadores, exigidas pela valorização do trabalho, incluindo aí o cumprimento de suas obrigações tributárias, entre outras em face do Poder Público.

A exceção para aplicação do direito penal ao caso de não recolhimento sistemático de tributos, deve ainda ser observada quando os demais meios coercitivos do Estado não se prestem a obter o ressarcimento dos tributos não pagos, logo, deve ser demonstrado que os instrumentos previstos no ordenamento se revelam absolutamente insuficientes e insatisfatórios.

Na hipótese de as diversas prerrogativas do Estado, na busca de seu crédito, não alcançarem os tributos não pagos, deve o direito penal ser aplicado. Isto porque, caso

\footnotetext{
${ }^{55}$ COMPARATO, Fábio Konder, O Poder de Controle na Sociedade Anônima, $6^{\text {a }}$ Ed. Rio de Janeiro, 2014, p. 419.
} 
determinado contribuinte, mesmo que de forma usual e de forma deliberadamente intencional declare e não recolha seus tributos, (deverá) poderá sofrer as diversas consequências previstas nas legislações de regência, como processo administrativo de cobrança, execução fiscal, medida cautelar fiscal, penhora on line de ativos, penhora de faturamento, protesto da dívida ativa, não obter certidão de regularidade fiscal, arrolamento de bens por parte do fisco, etc.

Neste caso, o resultado efetivo esperado é que o fisco obtenha os recursos que não foram pagos com os devidos acréscimos legais, sem maiores danos a coletividade, extinguindo inclusive a punibilidade por causa superveniente ${ }^{56}$. Apenas caso demonstre que a tutela ressarcitória não se revela efetiva para recompor o patrimônio não pago e ainda sem fazer cessar, o que é o mais importante, a própria prática ilícita do não recolhimento sistemático, poder-se-ia cogitar da aplicação da lei penal ${ }^{57}$.

Absolutamente diversa é a situação dos devedores contumazes, que podem ser definidos como "estruturas empresariais que têm na inadimplência tributária sistemática e consciente sua maior vantagem concorrencial" $" 58$, na qual o ressarcimento jamais será alcançado, pois a empresa intencionalmente não mantém ativos em seu nome e seus sócios são pessoas interpostas (laranjas) também sem bens.

Nestas hipóteses, a cobrança dos tributos é frustrada porque o devedor contumaz não possui patrimônio para satisfazer suas obrigações tributárias e, muitas vezes, faz parte de grupos empresariais que procuram ocultar os reais beneficiários dos ilícitos cometidos, praticando "uma macro delinquência tributária reiterada" (conforme voto do ministro Ricardo Lewandowski no RE 550.769). É tipo de devedor que desenvolve suas atividades de forma ilícita, ao adotar a inadimplência tributária como modus operandi empresarial, como se fosse

\footnotetext{
${ }^{56}$ Art. $9^{\mathrm{o}}$ É suspensa a pretensão punitiva do Estado, referente aos crimes previstos nos arts. 1o e 2o da Lei no 8.137, de 27 de dezembro de 1990, e nos arts. 168A e 337A do Decreto-Lei no 2.848, de 7 de dezembro de 1940 - Código Penal, durante o período em que a pessoa jurídica relacionada com o agente dos aludidos crimes estiver incluída no regime de parcelamento. (...).§ $2^{\circ}$ Extingue-se a punibilidade dos crimes referidos neste artigo quando a pessoa jurídica relacionada com o agente efetuar o pagamento integral dos débitos oriundos de tributos e contribuições sociais, inclusive acessórios.

${ }^{57}$ Exemplifica-se da seguinte forma a questão, empresário que intencional e sistematicamente deixa de recolher tributo por longo período e em montante expressivo, declarando, por sua vez, os tributos que deveriam ser recolhidos ao fisco, ao final ocorrido o autolançamento do tributo, o fisco ajuíza diretamente execução fiscal diante da declaração do valor do tributo pelo contribuinte ao fisco sequer há necessidade de processo administrativo tributário prévio-, e obtém ao cabo o ressarcimento ao erário com todos os pesados encargos moratórios. Trata-se de usual situação com irrelevância penal, mesmo que esteja se tratando de valores vultosos ou, ainda a presença de sistemático não recolhimento por longo tempo.

${ }^{58}$ Conforme voto do Ministro Joaquim Barbosa no RE 550.769.
} 
parte de seu objeto social, este sim deve sofrer as consequências penais previstas no art. $2^{\circ}$, inciso II, da Lei $\mathrm{n}^{\mathrm{o}}$ 8.137/1990.

Assim, o direito penal deve ser medida empregada pelo Poder Público para combater a reiterada e contumaz sonegação fiscal, apenas. E nem poderia ser diferente. Afinal, não se pode admitir a livre iniciativa de quem se presta a sistematicamente negar o dever de pagamento ao fisco, pois, nessa hipótese, não se está a falar em iniciativa econômica legítima.

Resta claro, então, que enquanto inexistir norma nacional específica que conceitue o devedor contumaz, somente caso demonstrada a reiterada utilização da sonegação fiscal como meio empresarial inidôneo, seja através da conquista de mercado através do baixo preço obtido com a evasão fiscal, seja através de longos períodos e vultosos valores, e desde que, cumulativamente, seja demonstrado que as medidas usuais no âmbito civil de ressarcimento ao Estado não se prestem à correção, nesse cenário então deve ser utilizada a lei penal.

Por outro lado, deve ainda ser assegurado um devido processo legal administrativo prévio para configuração da pecha de devedor contumaz e não que o procedimento criminal se revele a primeira oportunidade para que o contribuinte faça a prova da sua idoneidade ${ }^{59}$, afinal, "ainda que a constrição física não venha se consumar, a interferência dos atos de investigação preliminar, via de regra, já é suficientemente danoso aos direitos fundamentos do investigado" 60

\section{A aplicação do conceito de contumácia na jurisprudência após o leading case.}

Diante do fato de que o julgado da Suprema Corte ocorreu em 2019, existem poucos julgados que se debruçam sobre o recente entendimento do STF sobre a matéria.

Nesse sentido foram selecionados três recentes julgados do Superior Tribunal de Justiça ("STJ"). O primeiro o AgRg no REsp 1.865.750, julgado em 22.9.2020 ${ }^{61}$, no qual o

\footnotetext{
${ }^{59}$ Nesse sentido, alerta Luigi Ferrajoli: "não se pode desconhecer a possibilidade de fazer uso do processo como uma punição antecipada, ou de intimidação policialesca, ou de estigmatização social, ou de persecuções políticas ou por todos estes motivos conjuntamente". (FERRAJOLI, Luigi, Direito e Razão, Teoria do Garantismo Penal, 3ed. São Paulo, Revista dos Tribunais, 2002, p. 680)

${ }^{60}$ MAZLOUM, Ali, Reserva de jurisdição: Os limites do juiz na investigação criminal, $1^{\mathrm{a}}$ ed. São Paulo, Matrix, 2016. p. 72.

${ }^{61}$ (...). CRIME CONTRA A ORDEM TRIBUTÁRIA. ART. $2^{\circ}$, INCISO II, DA LEI N. 8.13790. NÃO RECOLHIMENTO DE ICMS NOS MESES DE JULHO, AGOSTO E OUTUBRO DE 2011. ENTENDIMENTO DO SUPREMO TRIBUNAL FEDERAL NO RHC N. 16.334SC. CONTUMÁCIA DELITIVA NÃO DEMONSTRAÇÃO. ATIPICIDADE DA CONDUTA. ABSOLVIÇÃO. RECURSO PROVIDO. (...) 4. O Plenário do Supremo Tribunal Federal, no julgamento do RHC n. 163.334, passou a considerar para a incidência do tipo previsto no art. $2^{\circ}$, II, da Lei n. 8.137/1990, a contumácia delitiva e o dolo de apropriação, decidindo que $o$ contribuinte que, de forma contumaz e com dolo de apropriação, deixa de recolher o ICMS cobrado do adquirente da mercadoria ou serviço incide no tipo penal do art. $2^{\circ}$, II, da Lei $n^{o}$
} 
STJ entendeu que três meses, de não pagamento de tributo, não se prestam a configurar contumácia, não fazendo qualquer referência ao valor envolvido não recolhido ${ }^{62}$.

Em similar entendimento o STJ, nos autos do AgRg no REsp 1.867.109, julgado em 25.08.2020, reconheceu a atipicidade da conduta por ter ocorrido o não pagamento de tributo em apenas um mês ${ }^{63}$. No mesmo sentido no REsp 1.852.129, julgado em 16.06.2020, reconheceu que quatros meses não se prestam a configurar a contumácia ${ }^{64}$.

Por sua vez, mesmo não se tratando de posição de Tribunal Superior, relevante colacionar posição do maior Tribunal de Justiça do País, o do Estado de São Paulo, que em 30.6.2020, entendeu pela tipificação da conduta pelo fato do empresário deixar de recolher o ICMS por dez meses e, o valor envolvido, ser superior a seiscentos mil reais. ${ }^{65}$

8.137/1990. 5. Tendo o recorrente sido condenado por deixar de recolher o tributo por três meses, nos meses de julho, agosto e outubro de 2011, inexistindo referência a ser agente contumaz ou sobre a existência de processo administrativo fiscal para apurar apropriação em períodos posteriores a esse lapso temporal, deve ser reconhecida a atipicidade da conduta.6. Agravo regimental provido para absolver o recorrente nos termos do art. 386, III, do Código de Processo Penal. (STJ, Min. Nefi Cordeiro - Sexta Turma, AgRg no Recurso Especial N 1.865.750 - SC, Brasília, Data de Julgamento: 22 .09.2020)

62 Tendo o recorrente sido condenado por deixar de recolher o tributo por três meses, nos meses de julho, agosto e outubro de 2011, inexistindo referência a ser agente contumaz ou sobre a existência de processo administrativo fiscal para apurar apropriação em períodos posteriores a esse lapso temporal, deve ser reconhecida a atipicidade da conduta. (trecho do voto condutor)

${ }^{63}$ (...) ART. 2. ${ }^{\circ}$, INCISO II, DA LEI N. 8.137/90. NÃO RECOLHIMENTO DE ICMS. TIPICIDADE DA CONDUTA. NECESSÁRIO COMPROVAR TAMBÉM A CONTUMÁCIA. ENTENDIMENTO DO SUPREMO TRIBUNAL FEDERAL PLASMADO NO RHC N. 16334/SC. CONDUTA QUE SE RESTRINGIU AO NÃO RECOLHIMENTO DO ICMS RELATIVO A UM MÊS (NOVEMBRO/2016). ATIPICIDADE RECONHECIDA. PRECEDENTE. AGRAVO REGIMENTAL PARCIALMENTE PROVIDO. (...)

4. Nos termos da jurisprudência do Superior Tribunal de Justiça, para o delito previsto no inciso II do art. $2 .^{\circ}$ da Lei n. 8.137/80, não há exigência de dolo específico, mas apenas genérico para a configuração da conduta delitiva. (...). 7. A Terceira Seção do Superior Tribunal de Justiça, no julgamento do HC n. 399.109/SC, pacificou o entendimento de que o não recolhimento do ICMS em operações próprias é fato típico. 8. Todavia, o Supremo Tribunal Federal, quando do julgamento do RHC n. 163.334/SC, cujo acórdão ainda está pendente de publicação, fixou a seguinte tese jurídica: "O contribuinte que, de forma contumaz e com dolo de apropriação, deixa de recolher o ICMS cobrado do adquirente da mercadoria ou serviço incide no tipo penal do art. $2^{\circ}$, II, da Lei $n^{\circ} 8.137 / 1990 " .9$. Na hipótese dos autos, portanto, inafastável a conclusão de que, conquanto o fato deletério atribuído ao ora Agravante, a princípio se subsuma à figura penal antes mencionada, a ausência de contumácia o débito com o fisco se refere a tão somente 1 (um) mês -, conduz ao reconhecimento da atipicidade da conduta e, por conseguinte, à absolvição do Réu com esteio no inciso III do art. 386 do Código de Processo Penal. 10. Agravo regimental parcialmente provido para absolver o Réu. (STJ, Ministra Laurita Vaz, Sexta Turma, AgRg no REsp 1.867.109/SC, Data do julgamento 25/08/2020)

64 (...) VIOLAÇÃO DO ART. $2^{\circ}$, II, DA LEI N. 8.137/1990. PROCEDÊNCIA. AUSÊNCIA DE CONTUMÁCIA DELITIVA (RHC N. 163.334). MOLDURA FÁTICA (EXTRAÍDA DA INSTÂNCIA ORDINÁRIA) QUE INDICA QUE A AUSÊNCIA DE RECOLHIMENTO DO ICMS DECLARADO OCORREU POR POUCO PERÍODO DE TEMPO (QUATRO MESES), INEXISTINDO MENÇÃO À REITERAÇÃO SUBSEQUENTE. ATIPICIDADE. ABSOLVIÇÃO. Recurso conhecido em parte e, nessa extensão, provido para absolver a recorrente, com fundamento no art. 386, III, do CPP. (STJ, Ministro Sebastião Reis Júnior, REsp 1.852.129/SC, Data do julgamento 16/06/2020)

65 "Nem se olvidando que mais recentemente, a c. Corte Suprema, nos autos do RHC n' 163.334/SC relatado pelo e. Min. Roberto Barroso, assentou a tese de que o contribuinte que, de forma contumaz e com dolo de apropriação, fazendo da inadimplência tributária seu modus operandi, deixa continuadamente de recolher o 
Depreende-se que após o julgamento do STF as decisões sobre a matéria ainda são excipientes, inexistindo sinalização clara da jurisprudência sobre a forma de definir o conceito preciso de devedor contumaz, razão pela qual o indesejado cenário de insegurança jurídica se encontra presente.

\section{Conclusão.}

Embora tanto o recolhimento tributário como o combate à criminalidade sejam nortes que orientem qualquer comunidade contemporânea, tais metas políticas não podem ser dissociadas de uma racionalidade juridicamente balizada na Constituição e pela lei.

A consonância prática e harmônica entre a norma infraconstitucional e a Constituição existe, ressalta Konrad Hesse ${ }^{66}$ "quando a lei admite uma interpretação que é compatível com a Constituição". De acordo com a iterativa e pacífica jurisprudência do STF, essa técnica "é utilizável quando a norma impugnada admite, dentre as várias interpretações possíveis, uma que a compatibilize com a Carta Magna" (ADI 1.344/ES, Ministro Moreira Alves).

O ambiente normativo brasileiro de negócios, em especial a legislação tributária, é marcado pela altíssima complexidade, não se devendo adotar medidas no campo penal que afetem negativamente o ambiente de negócios, afastando investimentos e aumentando o custo de investir diante do risco empresarial.

Como tratado, não se reveste de natureza absoluta a liberdade de atividade empresarial, econômica ou profissional, eis que inexistem, em nosso sistema jurídico, direitos e garantias impregnados de caráter absoluto. O particular pode usar a liberdade na gestão de seus negócios - sem dela abusar -, inclusive quanto ao momento de pagamento dos tributos. A noção de livre iniciativa pressupõe, como é elementar, o empreendimento de atividade lícita e a observância das normas jurídicas em vigor, inclusive as normas que impõem o pagamento de tributos.

O direito penal não deve ser, em regra, instrumento de política fiscal, devendo haver clara separação entre situações empresariais nas quais o inadimplemento é pontual em situações em que há inadimplência sistemática e deliberada, e ainda sem possibilidade de ressarcimento.

ICMS cobrado do adquirente da mercadoria ou serviço para incidir no tipo penal do artigo $2^{\circ}$, II, da Lei 8.137/1990. A condenação, enfim, se revela acertada, não havendo demonstração de qualquer excludente" (TJSP, AP n ${ }^{\circ}$ 0003615-44.2011.8.26.0347, $4^{\text {a }}$ Câmara de Direito Criminal, Rel. Ivana David, Data do julgamento 30/06/2020).

${ }^{66}$ HESSE, Konrad, in "Elementos de Direito Constitucional da República Federal da Alemanha", Porto Alegre: Sergio Antonio Fabris Editor, 1998, p. 80. 
Isto é, o direito criminal deve "agir" quando a inadimplência fiscal constituir elemento intrínseco da atividade empresarial, inclusive porque, em tais situações, independente das medidas legais adotadas pelo Estado, que jamais se verá ressarcido, e este não ressarcimento não ocorrerá por um eventual revés empresarial, decorrente do risco do negócio que restou mal sucedido, mas, sim, em decorrência de uma estrutura intencionalmente formada justamente para que não se consiga obter êxito em devolver tais valores ao Estado.

Há que reconhecer que a incidência da norma penal para as hipóteses de sonegação contumaz, substancial e abusiva, demonstradas mediante devido processo legal por parte de empresas que se valem dessa prática ilícita para obter ganhos ilegítimos, burlando a livre concorrência e deixando de contribuir ao Estado, e ainda com baixíssima previsibilidade de ressarcimento futuro através das medidas executórias ressarcitórias.

No atual cenário, destaca-se que o melhor caminho a ser percorrido é através do Congresso Nacional, que deve definir o conceito de contumácia, sendo certo que já há dois projetos de lei em tramitação sobre a matéria, que precisam ser aperfeiçoados para abarcar a hipótese tratada no tipo penal de que trata o art. $2^{\circ}$, inciso II, da Lei ${ }^{\circ}$ 8.137/1990.

Nesta toada, qualquer que seja o conceito legislativo de contumácia a ser adotado (quantitativo do valor envolvido, temporal sobre o tempo de não recolhimento, relação entre dívida e faturamento, ou ainda um mix entre diversos critérios, por exemplo), estará tal definição impregnada com a autoridade da legitimidade representativa inerente ao Parlamento, além de trazer segurança jurídica e menor margem hermenêutica.

O outro possível e premente cenário será, então, o STF definir com maior objetividade o conceito de contumácia, pois mesmo diante do extenso acórdão proferido pela Corte Constitucional, não é possível extrair elementos minimamente objetivos para direcionar a questão. Com isso, evitar-se-á que cada Autoridade Policial, Juiz, Ministério Público, Procuradoria da Fazenda, Auditor, etc., tenha seu próprio conceito de contumácia.

Enquanto o Congresso Nacional não avança nos projetos de lei sobre a matéria, o STF deve dar especial atenção para definir as balizas do devedor contumaz, devendo considerar, no conceito de contumácia, a comprovação de que as medidas estatais de cobrança do tributo se revelem ineficientes, pois, resta incompatível que determinado sujeito possa ser taxado como devedor contumaz quando o próprio Estado não possui dificuldades adicionais em obter os valores dos tributos devidos, através das medidas usuais de cobrança, com destaque à 
execução fiscal e adoção de medidas expropriatórias como penhora on line e leilão de bens penhorados.

Em conclusão, a bem da verdade, sem um conceito minimamente preciso de contumácia, conhecendo o histórico da sanha arrecadatória tributária, aliada ao punitivismo do Estado brasileiro sobre condutas financeiras, há grande chance de a priori se equiparar o devedor eventual ao verdadeiro devedor contumaz.

Tal cenário de insegurança jurídica se revela altamente indesejado e nocivo, pois ocasiona manifesto risco ao ambiente de negócios, com óbvio afastamento de investimentos, sendo que, em última análise, há inclusive real possibilidade de afetar a arrecadação diante da menor atividade econômica.

\section{Referências:}

ALFLEN, Pablo Rodrigo. Teoria do domínio do fato. São Paulo, Saraiva, 2014.

ANGELO, Tiago. Decisão STF: Equiparar dívida de ICMS declarado a crime é um erro, dizem advogados. Conjur, 2019. Disponível em https://www.conjur.com.br/2019-dez12/equiparar-divida-icms-declarado-crime-erro (acesso em 27.11.2020).

BITENCOURT, Cezar Roberto. Tratado de Direito Penal Econômico, volume 1, São Paulo, ed. saraiva, 2016.

BONAVIDES, Paulo, Curso de Direito Constitucional, São Paulo: Malheiros, 1998.

BOTTINO, Thiago do Amaral. MACHADO, Gabriel Soares dos Santos; A Criminalização do Inadimplemento do ICMS (Próprio). Revista da Faculdade Mineira de Direito, v. 22, n.44. 2019.

CAPPELlETTI, Mauro, Formazioni Sociali e Interessi di Gruppo Davanti Alla Giustizia Civile, Revista di Diritti Processuale n. 3, 1975.

COMPARATO, Fábio Konder, O Poder de Controle na Sociedade Anônima, $6^{\mathrm{a}}$ Ed. Rio de Janeiro, 2014.

ESTELLITA, Heloisa; JUNIOR, Aldo de Paula. O STF e o RHC 163.334: uma proposta de punição da mera inadimplência tributária? Jota: 2019. Disponível em: https://www.jota.info/opiniao-e-analise/colunas/penal-em-foco/o-stf-e-o-rhc-163-334-uma-

proposta-de-punicao-da-mera-inadimplencia-tributaria-10122019 (Último acesso: 27.11.2020) 
FERRAJOLI, Luigi, Direito e Razão, Teoria do Garantismo Penal, 3ed. São Paulo, Revista dos Tribunais, 2002.

HESSE, Konrad, A Força Normativa da Constituição, PA, Sergio Antonio Fabris, 1991.

HESSE, Konrad, Elementos de Direito Constitucional da República Federal da Alemanha, Porto Alegre: Sergio Antonio Fabris Editor, 1998.

MAZLOUM, Ali, Reserva de jurisdição: Os limites do juiz na investigação criminal, $1^{\mathrm{a}}$ ed. São Paulo, Matrix, 2016.

MORAES, Alexandre. Constituição do Brasil Interpretada. São Paulo, Atlas, 2005.

MULLER, Friedrich Discours de la Méthode Juridique, Paris, PUF, 1996

PAULSEN, Leonardo. Curso de Direito Tributário Completo. Saraiva, São Paulo, 8 ed. 2017. QUANDT. A apropriação indébita previdenciária e a prisão por dívida. In: LOBATO, José Danilo Tavares; MARTINELLI, João Paulo Orsini; SANTOS, Humberto Souza (Orgs.). Comentários ao Direito Penal Econômico Brasileiro. Belo Horizonte: D’Plácido, 2017.

RUIVO, Marcelo Almeida. Os Crimes de Sonegação Fiscal. 2019. (arts. $1^{\circ}$ e $2^{\circ}$, Lei 8.137/90), coletânea Crimes contra Ordem Tributária: do direito tributário ao direito penal. São Paulo: Almedina, 2018.

SILVA, Paulo Cezar. Crimes contra o Sistema Financeiro Nacional. São Paulo: Quartier Latin, 2006.

SOARES, Hugo. Podem ser legítimos crimes sem referência a bens jurídicos-penais? elementos para uma teoria sentimentalista do valor jurídico-penal. Revista Brasileira de Ciências Criminais, n. 147, 2018. 